\section{IL-17 inhibitors: good news, bad news}

\section{By Michael J. Haas, Senior Writer}

New partnerships and release of Phase III data highlight a flurry of activity this summer around the autoimmune target IL-17A. Now, emerging research suggests companies developing inhibitors of IL-17A signaling have both a repurposing opportunity and a new safety concern to navigate.

Findings by the Genentech Inc. unit of Roche suggest IL-17A inhibitors could treat cancers that are resistant to VEGF inhibitors. ${ }^{1}$ However, an academic team from Sweden and the U.S. reported that blocking IL-17A can destabilize atherosclerotic plaques and thus increase the risk of cardiovascular events. ${ }^{2}$

IL-17A is a member of the IL-17 family of proinflammatory cytokines, which have roles in allergy and autoimmune diseases. Another member of the family, IL-17F, shares about 50\% homology with IL-17A and is involved in airway inflammation in asthma. IL-17A and IL-17F function by binding a heteromeric complex that includes IL-17 receptor (IL17R; IL17RA) and IL-17 receptor C (IL17RC).

Multiple preclinical studies have shown that IL-17 cytokines and Th17 cells-a type of $\mathrm{T}$ helper cell that produces the cytokines-in the tumor microenvironment can promote tumor growth or stimulate antitumor immunity, depending on the cancer type and model studied. ${ }^{3}$ Moreover, the role of IL-17 cytokines in mediating tumor resistance to cancer therapies-such as anti-angiogenics that inhibit signaling between VEGF and VEGF receptor-has been poorly understood.

The Genentech team set out to study the mechanisms by which tumors develop the resistance that blunts the effectiveness of antiangiogenics. The group started by generating two mouse models-one from a lymphoma cell line that is resistant to VEGF inhibition and the other from a lymphoma cell line that is sensitive to VEGF inhibition.

Levels of Il-17a were higher in the resistant tumors than in the sensitive tumors.

In models with the resistant lymphomas, co-treatment with mouse antibodies against Il-17a and Vegf decreased tumor growth compared with the anti-Vegf antibody alone.

Similarly, in models of murine lung and colon cancers, antibodies against Il-17a and Vegf reduced tumor growth compared with the antiVegf antibody alone. The team chose those malignancies because tumor infiltration of Th17 cells is associated with poor prognosis in patients

Table 1. Opportunities and obstacles for IL-17 inhibitors. Studies by two independent teams suggest inhibitors of IL-17A signaling could help treat cancers that are resistant to VEGF inhibitors but could also destabilize atherosclerotic plaques and thus increase the risk of cardiovascular events. The findings therefore present a repurposing opportunity and a safety caveat to companies developing inhibitors of members of the IL-17 family or IL-17 receptor (IL17R; IL17RA) to treat autoimmune and inflammatory indications.

Source: BCIQ: BioCentury Online Intelligence

\begin{tabular}{|c|c|c|c|c|}
\hline Company & Compound & Target(s) ${ }^{\mathrm{a}}$ & Type & Status \\
\hline $\begin{array}{l}\text { Amgen Inc. (NASDAQ:AMGN)/ } \\
\text { AstraZeneca plc (LSE:AZN; NYSE:AZN) }\end{array}$ & Brodalumab (AMG 827) & IL17R & Antibody & $\begin{array}{l}\text { Phase III to treat psoriasis; } \\
\text { Phase II to treat psoriatic arthritis } \\
\text { and asthma }\end{array}$ \\
\hline Eli Lilly and Co. (NYSE:LLY) & Ixekizumab (LY2439821) & IL-17A & Antibody & $\begin{array}{l}\text { Phase III to treat psoriasis and } \\
\text { psoriatic arthritis; Phase II to treat } \\
\text { rheumatoid arthritis (RA) }\end{array}$ \\
\hline Kyowa Hakko Kirin Co. Ltd. (Tokyo:4151) & KHK4827 & IL17R & Antibody & Phase III to treat psoriasis \\
\hline Novartis AG (NYSE:NVS; SIX:NOVN) & Secukinumab (AIN457) & IL-17A & Antibody & $\begin{array}{l}\text { Phase III to treat ankylosing } \\
\text { spondylitis, psoriasis, psoriatic } \\
\text { arthritis and RA; Phase II to treat } \\
\text { multiple sclerosis }\end{array}$ \\
\hline 4SC AG (Xetra:VSC) & Vidofludimus (4SC-101) & $\begin{array}{l}\text { IL-17 expression } \\
\text { and dihydroorotate } \\
\text { dehydrogenase } \\
\text { (DHODH) }\end{array}$ & Small molecule & $\begin{array}{l}\text { Phase II to treat inflammatory bowel } \\
\text { disease }\end{array}$ \\
\hline $\begin{array}{l}\text { NovImmune S.A./Genentech Inc. unit of } \\
\text { Roche (SIX:ROG; OTCQX:RHHBY) }\end{array}$ & $\begin{array}{l}\text { NI-1401 (RG7624; } \\
\text { MCAF5352A) }\end{array}$ & IL-17A and IL-17F & Antibody & $\begin{array}{l}\text { Phase I to treat autoimmune } \\
\text { diseases }\end{array}$ \\
\hline AnaptysBio Inc. & ANB004 & IL-17 & Antibody & $\begin{array}{l}\text { Preclinical to treat autoimmune and } \\
\text { inflammatory diseases }\end{array}$ \\
\hline Covagen AG & COVA322 & $\begin{array}{l}\text { IL-17A and tumor } \\
\text { necrosis factor (TNF) }\end{array}$ & Protein & $\begin{array}{l}\text { Preclinical to treat inflammatory } \\
\text { diseases }\end{array}$ \\
\hline Ensemble Therapeutics Corp./Novartis AG & E-036041 & IL-17A & Macrocycle & Preclinical to treat arthritis \\
\hline Pieris AG & PRS-190 & IL-17 and IL-23 & Protein & $\begin{array}{l}\text { Preclinical to treat autoimmune } \\
\text { diseases }\end{array}$ \\
\hline
\end{tabular}

aUnless noted, the specific form of IL-17 (A, B, C, D E and/or F) inhibited by the compound is undisclosed. 


\section{ANALYSIS}

with lung and colorectal cancers.

Next, in models with resistant lymphomas treated with the anti-Vegf antibody, deficiency in $I l 17 r c$ decreased tumor growth compared with normal $I l 17 r c$ expression.

Finally, the team injected normal mice with either the VEGF inhibitor-sensitive lymphoma cell line or the same cell line modified to overexpress Il-17a. The anti-Vegf antibody decreased tumor growth in mice injected with the unmodified cells more so than in those receiving the Il-17a-overexpressing cells.

Taken together, the findings show IL-17A has a role in tumor resistance to VEGF inhibitors and that blocking IL-17A signaling could re-sensitize some types of tumors to those inhibitors, the team wrote in its Nature Medicine paper.

Napoleone Ferrara led the team while he was a fellow at Genentech. He now is a professor of pathology at the University of California, San Diego.

Roche, Genentech and Chugai Pharmaceutical Co. Ltd. market Avastin bevacizumab, a humanized mAb against VEGF, to treat breast,

\section{"It will be important to analyze cardiovascular events in patients treated with IL-17 inhibitors. We hope to do this in collaboration with our colleagues in the relevant academic disciplines and perhaps also with pharma companies." \\ - Göran Hansson, \\ Karolinska Institute}

brain, colorectal and renal cancers, non-small cell lung cancer (NSCLC), neurofibromatosis and solid tumors.

Genentech, Roche and NovImmune S.A. are co-developing an antibody against IL-17A and IL-17F to treat autoimmune diseases (see Table 1, Opportunities and obstacles for IL-17 inhibitors).

\section{Problems with plaque}

The Swedish-U.S. researchers wanted to know how signaling between transforming growth factor $\beta 1$ (TGFB1) and mothers against decapentaplegic homolog 7 (MADH7; SMAD7) affected subpopulations of $\mathrm{T}$ cells in atherosclerosis, but they discovered a role for IL-17A instead.

The team found Smad7-deficient mouse models of atherosclerosis developed plaques with larger, more fibrous caps than wild-type controls. The deficient mice also had higher numbers of Th17 cells in draining lymph nodes and higher levels of Il-6-which can trigger Th17 differentiation-in the plaques.

These results led the team to hypothesize that IL-17A produced by Th17 cells promoted the development of fibrous caps on the plaques.

Indeed, in the Smad7-deficient models a murine anti-Il-17a antibody decreased the size of fibrous caps on the plaques compared with a nonspecific murine control antibody.

In cultured human vascular smooth muscle cells, IL-17A increased levels of fibrous collagen compared with no treatment. Furthermore, the team's transcriptome analysis of 132 human atherosclerotic plaques identified positive associations between levels of IL-17A, fibrous collagen and a marker of smooth muscle cells.

The findings collectively suggest IL-17A secreted by Th17 cells promotes the production of collagen by vascular smooth muscle cells in atherosclerotic plaques, leading to the formation of fibrous caps on those plaques, the team wrote in Science Translational Medicine.

Because cap size is crucial to plaque stability, IL-17A inhibitors could

\section{TARGETS AND MECHANISMS}

potentially destabilize atherosclerotic plaques and thus increase the risk of stroke and other cardiovascular events, team co-leader Göran Hansson told SciBX.

To assess the extent of this risk, "it will be important to analyze cardiovascular events in patients treated with IL-17 inhibitors," he said. "We hope to do this in collaboration with our colleagues in the relevant academic disciplines and perhaps also with pharma companies."

Hansson is a professor of experimental cardiovascular research at the Karolinska Institute. Richard Flavell, chair of immunobiology at the Yale School of Medicine and an investigator at the Howard Hughes Medical Institute, co-led the team, which included researchers from Umeå University.

\section{Moving along IL-17}

In addition to monitoring the cardiovascular health of patients receiving IL-17 inhibitors, the Swedish-U.S. team wants to use its findings to develop therapies that could stabilize atherosclerotic plaques and thus reduce the risk of cardiovascular events in patients who have severe atherosclerosis.

However, "because IL-17 receptors are expressed on many cell types throughout the body, targeting IL-17 or IL-17 receptors directly could be hazardous," said Anton Gisterå, first author on the team's paper and a Ph.D. student in Hansson's research group.

Thus, according to Gisterå, the group is investigating specific plaquerelated molecules in the blood-vessel walls that could be targeted to mimic the effect of IL-17A on plaque stability.

He said the findings reported in Science Translational Medicine are unpatented.

According to Genentech spokesperson Nadine Pinell, the company has not yet determined whether it will conduct additional studies of IL-17A's role in VEGF inhibitor-resistant cancers.

Pinell declined to disclose the IP status of the Nature Medicine findings.

Haas, M.J. SciBX 6(31); doi:10.1038/scibx.2013.814

Published online Aug. 15, 2013

\section{REFERENCES}

1. Chung, A.S. et al. Nat. Med.; published online Aug. 4, 2013; doi:10.1038/nm.3291

Contact: Napoleone Ferrara, University of California San Diego, La Jolla, Calif.

e-mail: nferrara@ucsd.edu

2. Gisterå, A. et al. Sci. Transl. Med.; published online July 31, 2013; doi:10.1126/scitranslmed.3006133

Contact: Göran K. Hansson, Karolinska Institute, Stockholm,

Sweden

e-mail: goran.hansson@ki.se

Contact: Richard A. Flavell, Yale University School of Medicine, New Haven, Conn.

e-mail: richard.flavell@yale.edu

3. Fridman, W.H. et al. Nat. Rev. Cancer 12, 298-306 (2012)

\section{COMPANIES AND INSTITUTIONS MENTIONED}

Chugai Pharmaceutical Co. Ltd. (Tokyo:4519), Tokyo, Japan

Genentech Inc., South San Francisco, Calif.

Howard Hughes Medical Institute, Chevy Chase, Md.

Karolinska Institute, Stockholm, Sweden

Novimmune S.A., Plan-les-Ouates, Switzerland

Roche, (SIX:ROG; OTCQX: RHHBY), Basel, Switzerland

Umeå University, Umeå, Sweden

University of California, San Diego, La Jolla, Calif.

Yale School of Medicine, New Haven, Conn. 